\title{
Title: SME finance and the construction of value in Rwanda
}

\section{Abstract \\ Purpose}

This article explores how entrepreneurs, banks, the government and alternative lending respond to finance gaps for Small and Medium Enterprises (SME). This article considers valuation as a sociological construct where actors use different calculative devices, forming an assemblage that partly positions valuation of entrepreneurial finance as a contested and socially constructed process.

\section{Design/methodology/approach}

Drawing on the concept of 'calculative devices', the study articulates discursive institutional practices embedded within SME lending. This case study draws on analyses of 30 semi-structured interviews and archival data, government reports, and newspaper articles.

\section{Findings}

The study identified three triggers in Rwanda that were rooted in the informal and unincorporated nature of the SME governance structure; the lack of capacity for SME owners to manage their own projects; and normalising language around collateral requirements that marginalised the realities of SMEs; contributing to stagnation for SME finance.

\section{Practical implications}

The research provides direction for understanding how calculative devices create new forms of valuation of entrepreneurship in developing countries, particularly when human and non-human actors come together in an assemblage. The study calls for further research to demonstrate the embedded power of valuation practices and the performance of value in entrepreneurial finance.

\section{Originality/value}

The study brings new findings to the market creation literature by extending the notion of distributive calculative agency to SME finance. The study mobilises theory to interpret how discursive institutional practices are embedded within a country's finance infrastructure, yielding unintended consequences for SME growth. 


\section{Keywords}

Valuation; assemblage; calculative devices; alternative finance; Rwanda; SME finance (9,394 words)

\section{Introduction}

Abor et al (2014) highlight the importance of SME growth to a country's economic development. However, as Berger and Udell (2006) point out, market and institutional failures have hindered SME growth and exacerbated SME financing constraints globally. This study examines a group of Rwandan entrepreneurs who internationalised their supply chains and unintentionally hindered the ability of local banks to sufficiently meet their new lending needs. The entrepreneurs found themselves in an interstitial space between a small, traditional family-owned business and an established firm. Entrepreneurial finance issues, such as the ones faced by these entrepreneurs, are worth examining because of the legacy of informality in SMEs, particularly in sub-Saharan countries. Although several models of small business finance exist to facilitate both the informal and formal sectors (Biekpe, 2004), these entrepreneurs had outgrown these models but still lacked the structure necessary to qualify for mainstream financing. Hence, they had to source alternative finance to continue their growth.

This case uses valuation to examine how competing discourses affect the availability of SME finance in developing countries. Valuation is the process of producing worth based in part on reflection and interpretation by different sets of actors (Vatin, 2013), circumventing linear analyses of risk in SME financing. Of particular interest here is developing an understanding of the relationship between the SMEs, local banks and state institutions with regard to SME lending in Rwanda, East Africa. The analysis positions valuation as a sociological construct where different calculative devices and competing interests form an assemblage, thus rendering valuation partly as a contested and socially constructed process. 
While recognising that valuation depends upon cash flows and risk embodied in sets of mathematical models used by investors and banks (for a more detailed discussion, see J. Abor \& Biekpe, 2009; Kumar \& Rao, 2015), this article examines the subjective areas of valuation in order to impart critical new insights into the problems associated with SMEs' access to finance in developing economies. Thus, the article contributes to filling a lacuna in the academic literature on valuation and entrepreneurial finance.

Using empirical, qualitative methodology, the article considers different dimensions of valuation through a 'sociological' perspective rather than an entrepreneurial finance perspective. The article articulates the roles of physical, positional and imaginative performances (Beckert, 2010) within valuation in the context of the entry of a US-based startup called 'kountable' to the Rwanda market. The company aims to facilitate disintermediation away from traditional finance players by providing finance based on a differentiated credit rating rubric.

This article makes two primary contributions to literature on market creation. First, by applying Callon and Muniesa's (2005, p. 1236) notion of distributive calculative agency (all the operations, both human and non-human, that make goods calculable), the article attempts to show how the performance of value affects access to finance for SMEs in Rwanda. The four sets of actors (entrepreneurs, the banking sector, the state and alternative finance) in this study took different approaches to dealing with shortages of finance in Rwanda, reflecting different exercises of agency. These actors create an assemblage composed of people, things, texts, and technologies (Fredriksen, 2014), including human and non-human instruments, displacing human actors as the sole possessors of agency and thereby creating new forms of valuation for entrepreneurship in Rwanda. Second, through critical qualitative firm-level data on African SME experiences in accessing finance, the article seeks to mobilise theory that interprets how discursive institutional practices are embedded within Rwanda's finance infrastructure sector yielding unintended consequences for SMEs.

The article first discusses the theoretical framework that underpins the analysis and 
the case background, a brief discussion of the data, and the methodology. The next three empirical sections provide a phenomenologically-derived discussion on the perspectives of these actors, followed by a conclusion.

\section{Theoretical framework}

This study examines how value evolves to position sets of actors within an assemblage (market system) and the extent to which different stakeholders affect the economic and symbolic value of Rwanda's SME sector. As an organising concept, valuation highlights the power relationship that affects the calculative capacity of these actors to actually define value. Muniesa (2011, p. 26) defines valuation as 'something that something has by virtue of how people consider it'. Hence, valuation is interlaced with subjectivities bound up within 'symbolic connections made between goods and socially rooted values, as well as the aesthetic ideals held by the purchaser' (Beckert, 2010, p. 107). Muniesa (2011, p. 26) further argues that valuation is also 'something that something has as a result of its own condition and of its relation to other things'. This depiction emphasises both the reflective and interrelated agencies that underpin it. Hence, as will be shown in this study, valuation 'expresses, reinforces and challenges' a particular social and moral order in society, and is anchored in social practices (Beckert, 2010, p. 107). The shift in attention towards the activities and practices of valuation rather than merely the value itself opens up an avenue for considering value as a rich empirical and observable fact that can take many forms (physical, positional and imaginative) and can be generally described as a quality assigned to an event, object, organisation or person.

Differing calculative devices and technologies in SME finance exemplify how power is integral to a valuation assemblage. The asymmetric flows of information from SMEs, whether intentional or not, become a calculative agency for them, irrespective of how strong actors may be within the assemblage (Callon \& Muniesa, 2005). In response, the banks, originally in a weaker position because of these asymmetries, implement a relational lending model (Berger \& Udell, 1998, 2006). Here, banks employ loan officers as intermediaries to develop 
close relationships with borrowers over time. The loan officers facilitate monitoring and screening of SME operations through networks of personal relationships, enabling the banks to produce measures of valuation (Bessy and Chauvin, 2013). They also create and disseminate conventions within the market and ensure that the conventions become part of a 'ritualisation process' (Durkheim, 1912) of valuation.

This study uses Beckert's (2010) conceptualisation of physical, positional, and imaginative performance to deconstruct the value of entrepreneurial finance. The physical performance of a good is established in "knowing the "how-to" of using the good', whereas positional performance 'requires an agreement on the meaning of the goods within the relevant group' and is considered a public act because a third party is charged with assigning value. Lastly, imaginative performance occurs where the value transcends the 'materiality of the good', similar to positional performance, but here the purchaser of the good ascribes symbolic meaning to its value. Imaginative performance is constituted as a private act and the value is created and reinforced through ritualised practices (Beckert, 2010). Using Durkheim, Beckert shows 1) how symbolic values are constructed and attached to different goods and activities, and 2) how the 'relevant criteria' (Bessy \& Chauvin, 2013) for assessing value are contested and subjective.

Situating valuation as a process allows for exploration of the ways in which alternative finance in Rwanda is socially, economically, and politically relevant to economic growth in the country. For example, how actors participate in the stated aims of expanding SME finance results in changes to the 'economic' or 'symbolic' value of the sector.

\section{Case background}

In this case, the banks perceived the governance structures of local SMEs as being intertwined with informality, based on local practice. Jackson et al. (2008) refer to this as indigenous practice that also constitutes acts of resistance against the more standardised practices (in this case, the dominant valuation frame). Therefore, the banks sought to 
encourage the SMEs to use more transparent ways of reporting their business operations, bringing them into the 'public domain' (Jackson et al., 2008), to reduce the SMEs' reliance on indigenous, tacit knowledge. The banks extensively used relationship lending where loan officers collected soft information to help inform lending decisions, and mitigate the firms' opacity (Sahar \& Anis, 2016; Uchida et al., 2012). This approach was combined with transaction-based lending (based on contracts, proformas, and evidence of legal business operations).

In 2009, the Rwandan government started the creation of a nationwide credit reporting company to mitigate information asymmetries and reduce indigenous practices within the SME lending market (National Bank of Rwanda, 2010). Entrepreneurs' local practices and indigenous knowledge were combined with public knowledge to form a hybrid model of business in an attempt to conform to the new requirements. However, the resulting 'hybridization dynamic' (Jackson et al., 2008) further complicated the banks' efforts to provide financing because they had few tools to assess the value of the SMEs' operations. Despite such interventions, the entrepreneurs still needed to resolve their own financial needs outside of mainstream finance (Bruton, et al., 2015). Some of them turned to a US-based trade credit company named kountable, which made lending decisions based on signed contracts and social media connections.

This article identifies three triggers prompting the arrival of kountable: a lack of hard data on firms' activities, informationally opaque firms, and the internationalisation of the SME supply chain. Traditional banks were still the dominant actors because they could address some of the gaps in hard information from those SMEs seeking finance. However, the gaps continued to pose problems in valuation for the banking sector, thus limiting their ability to offer credit. 'Hard information' is quantifiable data that facilitates the calculation of returns on investment (including the preparation of a business plan, monthly cash-flow projections, audited books of accounts, and a track record of the firm's banking transactions (Berger \& Udell, 2006)). The requirement to provide such information presented a formidable barrier to 
many SMEs due to the informality and unincorporated nature of their operations, and their lack of experience or resources to meet the requirements. Furthermore, hard information facilitates transaction-based lending, which favours larger firms over SMEs.

The second factor was the banks' perceptions that local SMEs were 'informationally opaque' (Berger \& Udell, 2006, p. 2947). However, Jackson et al. (2008) show that the informal nature of SMEs in Africa through 'indigenous practices'. The banks' efforts to overcome the resulting information asymmetries included the acquisition of qualitative information (soft information) through interactions between loan officers and SME owners. Although soft information can be more suitable for assessing SMEs, it can deteriorate over time as it passes through the bank's communication hierarchy (Uchida et al., 2012). Furthermore, this type of calculative device relies on information that is 'difficult to encode numerically' and can thus be reinterpreted in the process. As such it forms a 'privileged, collaborative, and repeated relationship' between the banks and SMEs (Cotugno et al., 2013, p. 1372).

The third trigger occurred as a result of the entrepreneurs' expanding search for raw materials from suppliers outside the country and the region, making banks even less able to assess risk, thus diminishing their support in terms of SME lending.

These triggers hindered the government's ambitions to develop the sector and prevented SMEs from accessing larger sources of finance as their businesses grew. This created an ad hoc market force that allowed for a new model of alternative finance, derived through technological innovation, to join the assemblage in an effort to address the SME financing gap in Rwanda. The triggers present a unique discourse on valuation within the context of this assemblage of human and non-human actors.

The non-human actor emerged in the form of the US-based online finance platform, kountable, which began operating in Rwanda in 2014 as a pilot, going 'live' from April 2015. The platform used the entrepreneur's social media activity as a measure of creditworthiness, facilitating a disintermediation away from mainstream finance. Working as a locally registered 
information technology (IT) company, kountable raised money from investors globally to provide short-term funding for SMEs in Rwanda. Information was collected about the entrepreneur through a mobile app that used algorithms to analyse the entrepreneur's business networks on social media platforms (Facebook, Twitter, and LinkedIn), emails and mobile phone communications. Kountable gave each entrepreneur a 'k-score', on which lending decisions were based, and the company inserted itself into the global supply chain by purchasing raw materials or equipment on behalf of the entrepreneur. This marked a significant departure from microfinance models, the relationship lending model, and the 'traditional' crowdfunding model. Hence, the study seeks to use this case to clarify how the performance of value affects access to finance for SMEs and the extent to which discursive institutional practices yield unintentional consequences for SMEs in Rwanda.

\section{Methodology}

This case study analyses 30 semi-structured interviews, archival data, government reports, and newspaper articles. It employs a grounded theory approach where theory develops as 'it emerges from and generates explanations of relationships' (Lawrence \& Tar, 2013 , p. 31). Theoretical coding was used to analyse the events that reflected the 'lived experiences' of Rwandan SME owners in pursuing their business interests. Grounded theory includes a coding process to help 'make sense' of the data through systematically 'categorising and grouping similar examples from data' (O'Reilly et al., 2012, p. 248). We sought to create linkages between the data and their theoretical underpinnings by examining 'properties, dimensions, and boundaries' of the preliminary and final data categories.

For primary data, four groups of actors were identified through a preliminary literature review on SME finance in Africa: bank and state representatives (a senior manager from the state development bank and two credit reporting bureau managers), kountable senior managers, and SME owners who received financing from kountable. In the banking sector, senior credit administrators participated from the six commercial banks with the highest proportion of SME business in Rwanda. State perspectives were sought through 
interviews with the sole credit reporting agency and the sole state-run development bank.

Kountable facilitated access to the SME owners by sharing their client list. At the time of data collection, kountable had received over 286 SME applications of which they had approved 30, from 23 SME owners. In consultation with kountable's country manager, three clients were eliminated because their projects were considered sensitive in nature (for example, military contracts). Another two declined to be interviewed. Hence, 18 interviews were conducted with owners until we could identify no new themes for coding purposes (for a more detailed discussion of coding saturation, see Bowen, 2009).

Six credit administrators from the largest commercial banks were interviewed. Two banks were African (non-Rwandan), three were Rwandan, and one European. All interviews were recorded using AudioNote software, transcribed (three were translated from Kinyarwanda to English), and then coded using MAXQDA II software. The analysis employed the iterative process of grounded theory to 'name and compare events in the data' and look for similarities and differences (O'Reilly et al., 2012, p. 251), which resulted in 32 sub-themes. These themes were aggregated into four key themes through winnowing (Creswell, 2012). The analysis that follows, employing a iterative grounded theory method, requires a 'steady movement between concepts and data' (Lawrence \& Tar, 2013, p. 30). Hence, we systematically and discursively interrogated the data, constantly comparing types of evidence 'to control the conceptual level and scope of the emerging theory' (Lawrence \& Tar, 2013, p. 30).

\section{Findings}

The findings section looks at four distinct themes for consideration, including the role of the state, the tensions between the supply and demand of SME finance, the entrance of alternative finance for SMEs, and lastly, the calculative device of kountable.

\section{State intervention and the singularisation of credit}


As mentioned, in 2009 the government unsuccessfully attempted to correct a weak institutional structure by introducing a credit rating company with the stated purpose of standardising credit risk assessment. A regional credit reporting bureau manager (RJ2) identified four factors that contributed to the failure of this attempt:

- the lack of an integrated ID card system for citizens of Rwanda,

- the technological infrastructure needed to support the initiative,

- the legal framework,

- associated costs.

This participant further noted that Rwanda was a small market and would be not profitable for a firm to enter, particularly from outside Rwanda. However, in 2010, a different company, the Credit Reference Bureau Africa (CRB), entered Rwanda to begin the process of standardising credit valuation. Our participant commented that this entrance was not painfree:

The current bureau went through several iterations of costing models in the market where price was driven down and down further. Regrettably when a bureau business does not make sufficient margin it does not invest in that market and is unlikely to bring the advanced value adding products and services that follow - like credit scoring, automated decision systems, risk based pricing models. (RJ2).

The CRB initiative was designed to move SME operations toward the public domain, but also begin the uneven process of repositioning SMEs within the assemblage. However, the quote below shows that the state's own lack of capacity hindered the banks' ability to properly assess credit risk:

Governments and central banks need to play a role to facilitate financial inclusion. The real issue that you have with financial inclusion, we can loosely call it KYC (Know your customer). KYC policies didn't exist in Africa 15 years ago but now is in Africa and Asia as well. So the government has to ensure that they play a role in making KYC easy. So think about somebody who is running a small shop, street addresses in Africa are uncommon and identity documentation is also very scanty. So how is a bank supposed to include these people in their agenda if you don't even know where they are? So, banks and the SME owners are coming from completely different levels. What's available on the ground is so low and what the bank is expected to do is so high, you can never have common ground (RJ1). 
While the government intended to standardise credit information, it also needed to provide more basic services, such as identification cards, in order to hold banks responsible for ensuring that entrepreneurs had appropriate documentation for lending decisions. This attempt to standardise became a means of evidencing entrepreneurial activities in Rwanda for the purpose of developing evaluative value, which Holden and van Klyton (2016, p. 737) define as government efforts to use 'standardizing methods and means to visualize and measure their (economic) activities'. This idea of systematically bringing the informal economic activity into the public domain is also referred to by Callon and Muniesa (2005, p. 1232) as singularisation. The CRB's reporting would then 'classify, cluster and sort', providing affordances for the banks to reposition SME owners according to a new calculable rubric. The introduction of this system supplanted prior forms of valuation and consequently altered the interdependence and subjectivities within the assemblage, creating what Chiapello (2015) describes as financial colonisation.

The new measures provided the state with new calculative devices to alter how valuation was understood and practised in SME finance ${ }^{1}$, in alignment with the state's vision of itself as an aspirational modern economy (Scott, 1999). Nevertheless, this financial colonisation was not straightforward. Notice how a second CRB manager (RJ3) discussed the challenges involved in shifting valuation:

There is not much happening with non-finance SMEs; SMEs have their own way of managing business ... another thing is that selling on credit on the Rwandan market is not well developed, people expect you to come with cash or at least a cheque, but giving you like a computer and waiting for you to pay in three or four instalments is not really accepted here because of the culture and the market. (RJ3)

The new CRB's calculative device was universally applied, but resulted in low participation from SMEs. Instead, the small business owners continued to use their indigenous practices. The CRB manager further described the response of SMEs:

SME owners are aware of the benefit [of the CRB] but when they consider the workload and costs

\footnotetext{
${ }^{1}$ The government also adopted an SME Policy in 2010 with the aim of guiding the implementation of a coherent and coordinated framework thereby creating an enabling environment for the growth of the sector. This was further supported by annual increases in SME sector lending and a relaxation of collateral requirements for receiving loans.
} 
involved, they are reluctant [to participate]. Most of them do not have organised data and when the owner needs to produce that data for credit risk assessment, it needs to be organised. The owners look at that task and they feel like it is going to give them more work and they say that they can still manage their risk [without engaging with CRB]. (RJ3)

Although the CRB manager felt that the SMEs accepted the value of the new calculative device, it was not fully appreciated because the SMEs felt that the indigenous practices were sufficient. The introduction of the CRB was an exercise of positional performance by the state, 'classifying the SME owner by bestowing a certain social identity upon him' (Beckert, 2010, p. 111). Although valuation has the 'embedded potential to redefine human activities and public action' (Chiapello, 2015, p. 33), the SMEs' response shows how resistance can occur within an assemblage, materialising what Chiapello terms 'valuation struggles' that take place in the assemblage.

The state exhibited positional performance by attempting to (re-)construct value within the assemblage through this new third-party actor. The CRB was charged with ascribing symbolic value to SME activities and, in doing so, attempting to create new ritualistic practices through regulation (Durkheim, 1912) and by the hosting of workshops and forums to encourage SME owners to voluntarily report their activities. The workshops and forums were intended to strengthen the entrepreneurs' 'faith in the system' but also positioned credit reporting as the most important feature of SME activity. Furthermore, the CRB's mandatory requirement on banks reinforced the state's position within the assemblage.

Introducing credit reporting constructs particular ways of thinking about the value of business sectors but challenges the idea that 'buyers' use calculative tools that are 'more or less explicitly proposed to or imposed on them' (Callon \& Muniesa, 2005, p. 1239). While banks and large organisations adapted well to the new approach, SMEs struggled to meet its hard information requirements. The third-party agent (the CRB) was useful in ascribing value, but applied a universalist approach that ignored the ratio of hard to soft information for SMEs. In the end, the ritualistic practices that were intended to engage with the SMEs yielded limited success, which led the CRB to develop alternative instruments for them. 


\section{Building trust in the supply and demand for SME finance}

The problems associated with financing decisions within Rwanda's lending market can be tied to information asymmetries but also to the banks' perceptions of loose governance within SMEs. One credit manager claimed that management issues contribute to more than $60 \%$ of company failures, providing justification for the interventions and eventual emergence of alternative finance in Rwanda. Financial instruments can act as intermediaries, help to redefine valuation, and 'reorganize markets in different ways' (Bessy \& Chauvin, 2013, p. 83). However, they do not completely mitigate information asymmetry. One credit manager expressed the following:

The obstacles are mainly linked with the information which they don't have, the right or complete information which banks need. But also the management of SMEs is a problem because they don't have a clear governance system. There are just some family members there, they don't have a board and they don't have any structure. The SMEs give information that is not clear or complete about the ownership. So this is the problem because banks ask for requirements which the SMEs don't have and this will impact on their access to finance. (RJ4)

Notice how the condition is described by another credit manager below:

Most of the time it is a one-man shop. When they employ staff they do not declare their casual workers, making it difficult for us to see exactly how their business is run. Because if you come to me and say 'I'm having a turnover of 1 billion Rwandan francs', I expect to see a structure in place to manage that flow of money. This is turnover, so how many employees do you have? They can tell you that they employ people but are not able to give you evidence that they have people registered for tax purposes. They fail to do that and it is a big obstacle because sometimes they ask for a large amount of funding but the banks cannot give it to them. So the banks perceive that they don't have the management in place. (RJ6)

Here, the managers tie the struggle of SMEs to their 'informationally opaque' (Berger \& Udell, 2006, p. 2947) nature, reinforcing existing knowledge in the literature. The state and banking infrastructure produce discourses that socially construct deficiencies within the financial structure as being the fault of SMEs. Such social constructions of 'reality' simply become the reality (Luckmann \& Berger, 1966), particularly for weaker actors within the assemblage. The discursive language and actions described above show that the banks blame the SMEs for their own condition. However, the four sets of actors are interdependent and, as such, the 
conditions that affect the SMEs have repercussions for the entire assemblage. Ironically, as shown with the lack of street addresses, the perceived vulnerability of SMEs in fact mirrors the government's own informational opaqueness.

Banks rely on relationship lending to reduce information asymmetries with SMEs through the collection of soft information. Loan officers are heavily 'involved in the activity of valuation' (Bessy \& Chauvin, 2013, p. 84) through their interactions with entrepreneurs. However, this method is still problematic because of vulnerabilities inherent in the production and use of soft information. The following quote from a credit manager illustrates how soft information manifests itself in practice, and its vital role in developing client relations:

We do have what we call know your customer (KYC), I have to know my customer well, his family, type of business, possibly his friends too. I gain the client's confidence so that even if the client faces a problem he or she will come straight to me. I have to maintain that close relationship. Once the loan has been granted that doesn't mean the relationship stops, rather it is there when the relationship starts... I am in charge of following the whole process. (RJ7).

Another credit manager described the relationship he maintains with clients:

As a relationship manager, what you do you develop a relationship with a client where you end up becoming like his or her relative. If you don't build a strong relationship, the next day the competitor will take them away. So if my client is having a wedding party for her or his daughter or son and I don't show up he will take it personal, you have to go to the weddings and funerals. Unless the client faces some risk that the bank cannot bear, in most cases the bank always comes around to reduce the interest rates for such a client. (RJ8)

Relationship lending serves as a space where loan officers are active players in creating trust with SME owners, thereby shaping the lending market and reorganising behaviour. However, there are limitations in the use of these strategies, as shown below:

Most SMEs have accounts in all the banks, not because they are a big business but those accounts help them to divert business finance. So, SMEs who receive government contracts, those people are very dangerous because even though the terms and conditions of the contract specify which bank the money will be channeled into after payment, but I don't know, somehow they can arrange by themselves to change these terms to divert the payment into another account (RJ9).

We deal with SMEs, we visit and advise them. Most issues come from poor management in the sense that they mix everything so we advise them. So, you have someone running a family business but also dealing with other businesses like transport, general trade or housing, but they don't have strong 
financial records. Then come problems with the Rwanda Revenue Authority (tax office). When you deal with tax issues, the next day come fines, and next they are out of business (RJ10).

These reflections illustrate how relationship lending can be risky, irrespective of efforts to mitigate information asymmetry. Relationship lending can be undermined by intentional underrepresentation. Loan officers use soft information to intervene in the behaviour and activities of SMEs to 'construct, maintain and expand' the bank's market within the sector and create changes in 'the economic and symbolic value of a product' (Bessy \& Chauvin, 2013, p. 84). However, the SMEs' structures are not always aligned with this vision.

As observed, banks perceive SMEs as poorly managed, justifying their categorisation as a high-risk sector. However, as one credit manager shows, this may be a misperception:

There is the whole issue of the lack of discipline for SMEs to even maintain books of accounts and to maintain them accurately. Often it is actually an issue of bandwidth and accounts and just is this important or should I be running around getting more business and trying to figure out what my suppliers are doing'. So it becomes chaos rather than the SMEs being dishonest. But until they find a balance between maintaining books of accounts and being transparent about what's happening in their business, banks will have a problem in dealing with them. (RJ1)

The manager is indicating that rather than outright deception, entrepreneurs may simply lack the capacity to manage their operations well. Hence, this second discourse leads the banks to perceive a lack of transparency in the SMEs. The quotes below show how some banks situate transparency within SMEs, and their response:

The obstacles (for SMEs) are mainly linked with the information they don't have, the right or complete information which banks need. But also the management of SMEs is a problem because they don't have a clear system...They use family members, they don't have a board or a clear structure. While banks generally need information, SMEs give information that is not clear or complete. Even the ownership is not clear. So this leads banks to ask for requirements which the SMEs don't have and they cannot access finance. (RJ11)

The primary responsibility for managing the business goals is the business owner. They have full control; however, the moment somebody leaves the bank with money, the bank takes on liability. So we take some shareholding of the business. We buy some shares in the business to have some control and take part in recruiting a general manager. We have a better sense of control because we're getting someone on the board that we trust. So that's one of the solutions. (RJ12)

By some banks taking on part ownership, they occupy two opposing roles within the 
assemblage, further weakening the SME's calculative devices. Using van Hoyweghen's (2014, p. 344) work, this study argues that a bank's entering the company as part owner, with its pre-designed calculative devices, standardises from within and transforms the SME owner into an abstract object that is 'placeless, timeless and contextless'.

However, SME owners expressed that banks focus on the wrong aspects of their projects, particularly 'over reliance' on collateral guarantees:

\begin{abstract}
If someone wants to borrow 60 million Rwandan francs ( $\$ 80,000$ USD), he presents a business plan that he paid a local agent $\$ 200$ to create. He gives that $\$ 200$ and gives the agent figures to put in to show that the business is profitable; yet the bank knows that it is not [correctly valued] so the bank agrees to give you 30 million Rwf based on their assessment. Then if the bank looked closer they would find that the owner does not have the capacity to run the business. So when banks do their analysis, the entrepreneur is the person you have to really look at. So the banks are emphasising the wrong thing by focusing on collateral. (SME1)
\end{abstract}

Another big issue is that banks do not cover the project value, they cover the property (collateral). They finance based on property. They finance according to the guarantee that you have submitted. Sometimes in the middle of the project, the project becomes unrealisable because the bank will give you a smaller amount of money than requested, which cannot finalise the project quickly. If the project is $€ 325,000$ you might be given 200 million Rwandan francs $(€ 225,000)$. So you cannot complete the project because it is underfunded. (SME2)

Here it shows that different sets of actors construct different conceptions of sources of value. Hence, the entrepreneurs do not trust the banks to accurately value their projects for creditlending decisions. However, the banks, as suppliers of finance, have expressed similar distrust in entrepreneurs. It is common practice for entrepreneurs to maintain two financial statements: one that is presented to the bankers to meet the beliefs, norms and rules that underpin valuation, and another for internal use that more accurately represents the SME's circumstances.

The quote below further emphasises the dialectic relationship between the banks and SMEs with respect to valuation of SME activity.

To be on top of their business you need regular follow up of entrepreneurs' activities, asking them to show the internal and non-audited balance sheets so as you can look at them and understand the 
business. They operate several accounts from different banks not because of the size of the business but (rather) these accounts serve to divert business (RJ13).

Hence, loan officers have begun asking for these internal financial statements, acknowledging their value in the lending decision-making process. In this way, the loan officers use their relationships and insider knowledge to improve the quality of information and narrow the information gap. This is in line with the stated role of intermediaries as contributing to 'defining valuation' and 'fostering valuation frames that can improve the coordination of actors, but also reorganize the markets in different ways' (Bessy \& Chauvin, 2013, p. 83).

\section{Alternative finance for mid-experience SMEs}

The kountable platform emerged as a digital intermediary with the potential to exploit deficiencies in Rwanda's lending market. The model connects borrowers and lenders through a mobile application to meet the needs of a specific group of business owners.

As Figure 1 below shows, the entrepreneurs must first secure a contract with a buyer, then initiate negotiations with a supplier for raw materials. They must allow kountable to access their social media accounts by downloading and activating the mobile app. The entrepreneur then uploads the buyer's contract, the supplier proforma, and other evidence of a legal business operation (registration licence, address, pictures of the SME owner and of their fingerprints etc.) 


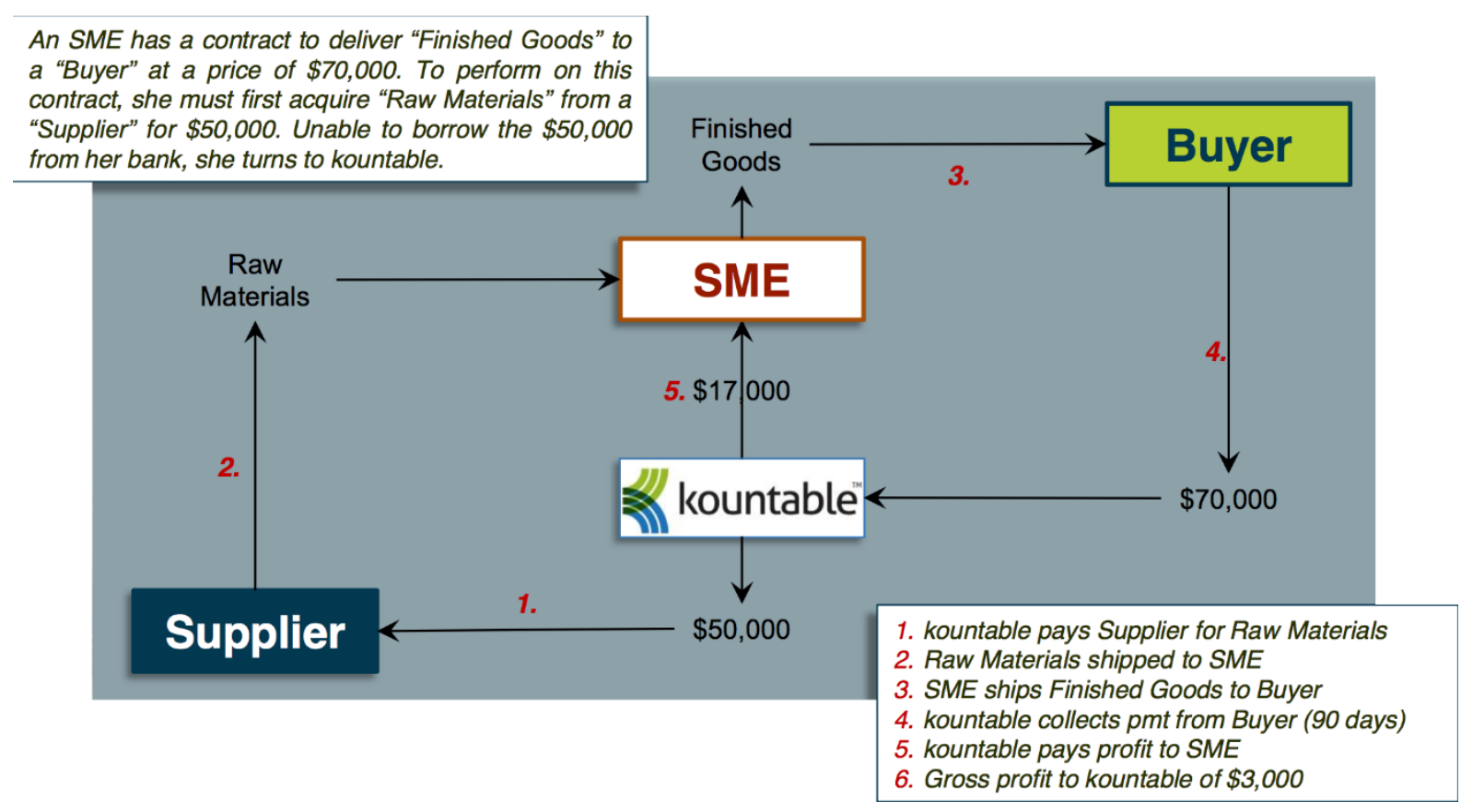

Figure 1: kountable Model; Source: https://www.kountable.com/

The kountable app facilitates borrowers' access to lending markets outside Rwanda and outside of the institutional structure that enables and constrains them. In the quote below, the CEO of kountable articulates his view on the demands for finance:

The products that were available and being offered by the traditional banking sector were actually not the products that these entrepreneurs really needed. They needed high-velocity, short-term capital. They didn't really want, you know, a three-year term loan for $\mathrm{x}$ number of dollars. Because you don't know, as a growing entrepreneur, especially one in an economy with as many opportunities as Kigali what your long-term needs will be. You don't know what your opportunity set is because you might secure a $\$ 200,000$ line of credit and the next week you win a $\$ 500,000$ contract, what are you going to do? So you need a product that actually is as nimble, as flexible, and as quick as the cycle of your business is. (KO1)

In addition to the lack of relevance of traditional financial products, the SME owners reported facing new obstacles as they internationalised their supply chain: lengthy processing times for loans and longer shipping times. Note the scenario that one entrepreneur describes:

Failure to execute a contract on time is the other reason SMEs incur payment penalties from banks. For example say in January 2016 you win a contract of 5 months in which you have to ship some raw 
materials to China. The bank will normally take the whole of February to process the loan, and then transport and shipping can go up to two months. This leaves you with one month to execute the contract in which case it can be difficult to get paid on time. (SME3)

As this shows, both kountable and the entrepreneurs perceive the financing shortage to be the banks' fault. The lack of responsiveness by the banks to changing market conditions further pushes the entrepreneurs toward alternative forms of finance.

\section{The k-score as a calculative device, but for whom?}

The kountable platform generates a k-score to assess the creditworthiness of SMEs based, in part, on the applicant's social media activity. Hence, this calculative device repositions information asymmetry and adverse selection within the assemblage. In addition, the model employs a local country manager who possesses the same insider knowledge as the borrowers, enabling them to bridge indigenous practices with public knowledge, thus following the hybridisation dynamic (Jackson et al., 2008). Notice how this country manager attempts to monitor and deter moral hazard using the k-score:

The K-score is like a checklist showing all stages and timing for the delivery process until the good has been received. The SME is expected to confirm back to kountable through regular communications. If he stops communicating, then we start questioning and the K-score will decrease. Kountable encourages truthful communication because it does not hurt the K-score to stay in touch, instead it keeps increasing even in case of delays in the contract execution. (KO2)

Although the k-score prompts communication, one of kountable's indications of creditworthiness, applicant manipulation can still occur. Figure 2 is a visualisation provided by kountable illustrating how they capture the social media activity of an applicant. However, they have no way of verifying if these points of contact constitute business-related communications. 


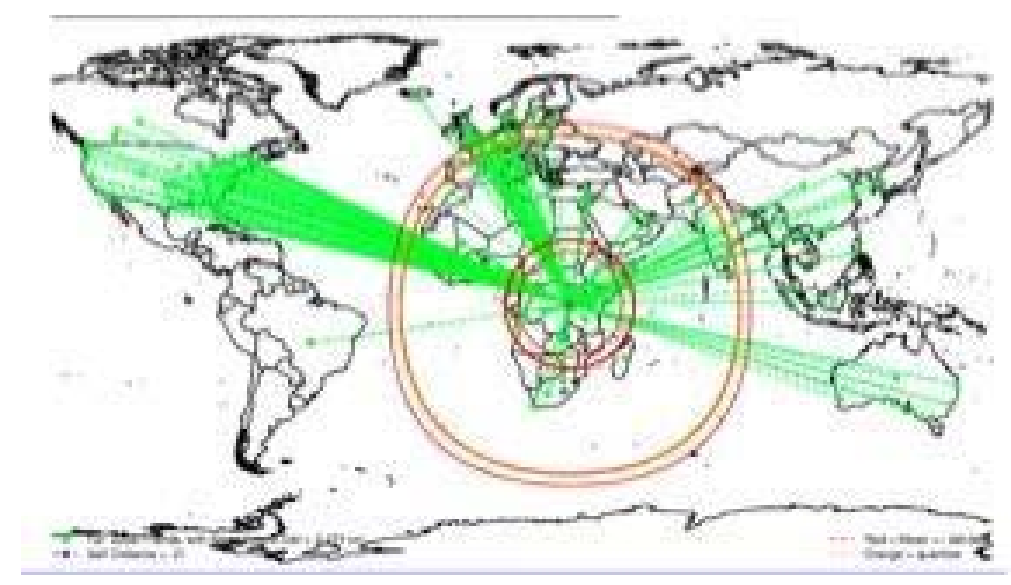

Figure 2: Network Map for kountable client

The quote from one entrepreneur below materialises the imaginative qualities of a product by arousing 'images that alter the state of the consciousness' (Beckert, 2010, p. 110), bridging the gap between the subject and the (intangible) ideal:

The first time I had the k-score it was $121 . .$. Then I noticed that when I got a lower score, I had delayed (communication with kountable) somewhere, the communication is not verifying and once I stimulated my communication back to them saying that someone is coming back from the airport or that I just returned from the Minister of Health, I saw my score going back up. So it is based on my communication (SME4).

The value captured by the k-score illustrates how symbolic value occurs (Beckert, 2010). On interpreting his k-score, he is 'ascribing symbolic meaning' and value to the good (Beckert, 2010, p. 116), which begins to shape SME behaviour. Kountable can absorb many aspects of the SME owners' indigenous practices of oral (and digital) communications into its calculative device. The banks and the state, however, deem these practices as loose governance and valueless and thus do not include them in their calculative devices.

Acceptance of this new product was not automatic. For one entrepreneur, sensemaking was used to develop trust in the unobservable characteristics of kountable, as the quote below shows:

Kountable does not have bureaucracy. Once you sign your contract with a pen from your mobile. The first time I was thinking these people are not serious. They want to [scam] and then in the end they will say oh... because we are fearing from the people of Nigeria. So I asked him, 'are you a white man or are 
you from Nigeria' (he laughs). He said go to Skype and then we talk, so that I could see that he was a white man. After seeing that I said okay let me sign because otherwise it would have been useless. (SME5)

This response is in line with Beckert's (2010, p. 109) discussion of positional performance, where the respondent's perception of value does not depend on 'its assessed (promised) transformative power in the physical world but on its capability to position its owner within the space of a differentiated social world'. For the entrepreneur, physically seeing (through Skype) a white man as the head of kountable gave him confidence because of the symbolic associations already attached to whiteness. Hence, objectivity was 'not anchored' on the product but rather on its ability to position the CEO as distinct from perceptions of dishonesty and fraud, which the entrepreneur associated with Nigerian scam artists.

\section{Discussion - vulnerabilities within the assemblage}

A manager within the CRB reiterated the concerns expressed by the traditional banking sector; namely, that SME owners were still ill-equipped to fully embrace this new system of valuation. The CRB's performing the public act of ranking and reporting SME activity serves to reframe valuation and makes the CRB product not just purely illusory. This article argues that, over time the CRB would potentially become the material representation of SME operations. However, as Durkheim (1912, p. 240) argues, moral forces, like those embedded in the credit reporting system, maintain no 'internal bonds to the various supports on which they come to rest'; rather, they draw on external and material forms for representation and then become superimposed on the SMEs who are obliged to follow them, which leads to compliance rather than 'success'.

From the findings, it was apparent that the entrepreneurs were exercising resistance. First, they expressed disquiet around the collateral requirements imposed by the banks. The opposing perspectives of SMEs and the banks worsen the mismatch problem between the 
supply and demand of finance, showing that agreement had not been reached in the positional performance of the value of the product (Beckert, 2010). Second, these entrepreneurs' discourse suggests resistance to the 'normativising power' of institutional language regarding collateral requirements. The owners felt that their realities and conditions were being ignored by the banking sector and the state. Third, although unquestionably illegal, the entrepreneurs' practice of maintaining two balance sheets also represents resistance to entering the public domain (Jackson et al., 2008). These interactions show that competing conceptions of sources of value between the supply and demand of finance occur because valuation is socially constructed and linked to power (Aspers, 2008).

The k-score and local country manager together become part of this assemblage that kountable is attempting to reshape. However, the bank and state dominance remain for two reasons: First, they possess 'more advanced calculative capacities and strong institutional involvement' (Çalışkan \& Callon, 2010, p. 13), which could be used to suppress weaker members of the assemblage. Second, inequalities persist within the assemblage that 'loop back' (Fredriksen, 2014, p. 11) to strengthen the state and the banks' positions, allowing them to dictate how valuation is enacted. The kountable model, as a new entrant, has not yet established ritualistic practices (Durkheim, 1912) to reinforce its value or provide entrepreneurs with a frame of reference for its use. However, kountable has empowered some entrepreneurs to modify their own calculative devices, whereby they can rely on indigenous practices while being systematically compelled to use social media.

The discourses used by banks and the state, stronger actors within the assemblage, point to the informal SME governance structures (indigenous practices and opaque information) and SME owners lacking the capacity to manage their projects as justification for banks to buy shares in these companies and appoint general managers to run them. This further weakens the entrepreneurs' position within the assemblage. Furthermore, banks employed language that normalised collateral requirements and ignored the realities and conditions of the SMEs. Given the importance of discourse to an assemblage (Çalışkan \& 
Callon, 2010) the SME owners would probably remain weak and not be inclined to move toward the public domain? Kountable's use of alternative risk assessment may reinforce the SMEs' position outside of the public domain, by merely digitising indigenous practices.

These vulnerabilities are a consequence of an unequal distribution of power within the assemblage. First, although kountable can be perceived as a solution to SME financing shortages, it registered in Rwanda as an IT company to provide trade finance services and not as a financial services firm. Hence, the firm falls outside of state policies and regulation designed to protect the financial sector. Furthermore, the kountable model has not eradicated information asymmetry, thereby potentially increasing the risk of default as their services expand.

Second, this model does not encourage entrepreneurs to develop an export economy as kountable would need the buyers to make their payments into the local bank account owned by kountable. Furthermore, the company would no doubt prefer that buyers be based in a country where the country manager could intervene in cases of default. Third, kountable is susceptible to capital controls. This US-based company faces the possibility of bottlenecks in repatriating profits from their local business due to the same shortages of foreign currency (Sherpa, 2013) that affect the entrepreneurs they are serving. These vulnerabilities indicate that kountable's calculative device 'may not muster enough institutional and political support' (Fourcade, 2011, p. 1724) to be included in mainstream finance. These vulnerabilities could undermine the bank and state's efforts to bring the SME sector into the public domain, thereby diminishing SMEs' contribution to economic growth in Rwanda.

\section{Implications for Theory and Practice}

The interactions described above between stronger and weaker stakeholders within the assemblage illustrate how different calculative devices within the performance of value are built upon different equipment constituting them, which results in weaker and stronger devices (Çalışkan \& Callon, 2010). This serves to reinforce a dialectic relationship between the 
SMEs and the banks. The entrepreneurs' exercising resistance to the dominant valuation frames (Vatin, 2013, p. 43) counters Bessy and Chauvin's (2013, p. 103) argument that valuation frames can come from a 'plurality of intermediaries that share the same conception of what constitutes the value of a product'. As such, the SMEs acts of resistance constitute their efforts to ascribe their own symbolic value over a third party's valuation; thus prioritising imaginative performance over positional performance, which is then reinforced through ritualised practices.

This article also identified sources of discursive institutional practices derived from third parties (the banks and the CRB) to superimpose dominant valuation frames on SMEs despite their resistance. The banks relied on relationship lending models to identify, assess and then interpret the indigenous practices of the SMEs in order to produce meaning within the dominant valuation frames of the banks. By comparison, the CRB's credit reporting system constituted a public act of positional performance that attempted to reinforce particular valuations; which proved ineffective because the root causes of a lack of capacity within the SMEs had not been adequately addressed. To some extent, each stakeholder group is deficient in terms of contributing to an assemblage that is mutually benefitting all stakeholders. Hence, it is critical that the calculative devices within this assemblage align themselves more equitably to bring the SME sector into the public domain to increase the robustness of the SME sector. This can be achieved through greater consultation across all stakeholder groups to assess the needs of SMEs and banks in developing policy for SME development.

\section{Conclusion}

The constitution of this assemblage was found to produce narratives that foregrounded and reinforced the problems endemic in Rwanda's financial market. Each actor deployed different calculative devices to address the problem, highlighting different dimensions of valuation. The study emphasised how physical, positional, and imaginative 
performances are brought to life through the deployment of these devices.

Valuation is contested and uneven, and binds together actors with different and competing interests. The first actor, the state, introduced market interventions including standardisation practices to move SMEs away from indigenous practices and into the public domain. The banks used relationship lending to complement the hard information requirements, while SME owners used indigenous practices as part of their calculative devices. SME operations were seen as less structured, and banks became reluctant to extend them credit. This situation became worse as SMEs began to internationalise their supply chain. The fourth actor, kountable, attempted to facilitate disintermediation away from mainstream finance by shifting some of the calculative capability away from human agency towards a new calculative device, the k-score.

This article has illustrated how physical, positional, and imaginative performances affect the construction of calculative devices. For SMEs, physical performance, the 'how-to' knowledge, underpins the construction of their calculative device because the criteria used to evaluate a good's quality are based on 'social conventions', where qualities are 'not only measured through judgment devices but are established by them' (Beckert, 2010, p. 114).

Positional performance implies that agreement must be reached by the actors in the assemblage to close the financing gap for small and medium businesses. Presumably, this would be spearheaded by state policy and its calculative devices that serve to situate participation in the public domain as a desirable social identifier, bestowable upon SME owners. Non-agreement, however, would complicate the effectiveness of a valuation system (Beckert, 2010, p. 114). Hence, SME owners must subscribe to the meanings associated with the dominant calculative devices for the banks to meet the financing needs of the SMEs.

Imaginative performance explains the function and effects of non-human actors within the assemblage. For the entrepreneurs, the k-score took on a symbolic value that transcended the material and became a calculative device, facilitating the internationalisation of the SMEs' supply chains. This device also became a form of resistance against the dominant 
discourses of valuation constructed by the more powerful actors within the assemblage. Beckert (2009, p. 264) argues that the 'constitution of actor preferences are explained based on normative, cultural, and social structural influences stemming from the social context in which market actors live'. This suggests that any valuation system should be derived from a critical understanding of the social context within which the actors are based. This creates an opportunity for further research into how physical, positional and imaginative performances can be catalyzed to facilitate greater access to finance for SMEs, particularly in developing countries. 
References

Abor, J., \& Biekpe, N. (2009), How do we explain the capital structure of SMEs in subSaharan Africa? Evidence from Ghana. Journal of Economic Studies, Vol. 36 no. (1), pp. 83-97.

Abor, J. Y., Alagidede, P., Ocran, M. K., \& Adjasi, C. K. D. (2014), Developments in the financial services sector in Africa. Review of Development Finance, Vol. 4 No. 2, pp. 63-65.

Aspers, P. (2008), Knowledge and valuation in markets. Theory and Society, Vol. 38 No .2, pp. 111-131.

Beckert, J. (2009), The social order of markets. Theory and Society, Vol. 38 No. 3, pp. 245269.

Beckert, J. (2010), The Transcending Power of Goods: Imaginative Value in the Economy. In The worth of goods -valuation and pricing in the economy (pp. 101-128). Oxford University Press, Oxford, UK.

Berger, A. N., \& Udell, G. F. (1998), The Economics of Small Business Finance: The Roles of Private Equity and Debt Markets in the Financial Growth Cycle. Journal of Banking \& Finance, Vol. 22, No. 6-8, pp. 613-673.

Berger, A. N., \& Udell, G. F. (2006), A more complete conceptual framework for SME finance. Journal of Banking \& Finance, Vol 30 No. 11, pp. 2945-2966.

Bessy, C., \& Chauvin, P.-M. (2013), The Power of Market Intermediaries: From Information 
to Valuation Processes. Valuation Studies, Vol. 1 No. 1, pp. 83-117.

Biekpe, N. (2004), Financing Small Businesses in Sub-Saharan Africa. Journal of African Business, Vol. 5 No. 1, pp. 29-44.

Bowen, G. A. (2009), Document Analysis as a Qualitative Research Method. Qualitative Research Journal, Vol. 9 No. 2, pp. 27-40.

Bruton, G., Khavul, S., Siegel, D., \& Wright, M. (2015), New Financial Alternatives in Seeding Entrepreneurship: Microfinance, Crowdfunding, and Peer-to-Peer Innovations. Entrepreneurship Theory and Practice, Vol. 39 No. 1, pp. 9-26.

Çalışkan, K., \& Callon, M. (2010), Economization, part 2: a research programme for the study of markets. Economy and Society, Vol. 39 No. 1, pp. 1-32.

Callon, M., \& Muniesa, F. (2005), Peripheral Vision Economic Markets as Calculative Collective Devices. Organization Studies, Vol. 26 No. 8, pp. 1229-1250.

Chiapello, E. (2015), Financialisation of Valuation. Human Studies, Vol. 38 No. 1, 13-35.

Cotugno, M., Monferrà, S., \& Sampagnaro, G. (2013), Relationship lending, hierarchical distance and credit tightening: Evidence from the financial crisis. Journal of Banking \& Finance, Vol. 37 No 5, 1372-1385.

Creswell, J. W. (2012), Qualitative Inquiry and Research Design: Choosing Among Five Approaches (3rd edition). Los Angeles: SAGE Publications, Inc.

Durkheim, É. (1912), The Elementary Forms of Religious Life. (M. S. Cladis, Ed., C. Cosman, Trans.). OUP, Oxford, UK.

Fourcade, M. (2011), Cents and Sensibility: Economic Valuation and the Nature of "Nature." 
American Journal of Sociology, Vol. 116 No 6, pp. 1721-77.

Fredriksen, A. (2014), Assembling value(s): What a focus on the distributed agency of assemblages can contribute to the study of value. The Leverhulme Centre for the Study of Value, No. 7, pp. 1-16.

Holden, K., \& van Klyton, A. (2016), Exploring the tensions and incongruities of Internet governance in Africa. Government Information Quarterly. Vol. 33 No. 4, pp. 736-745.

Jackson, T., Amaeshi, K., \& Yavuz, S. (2008), Untangling African indigenous management: Multiple influences on the success of SMEs in Kenya. Journal of World Business, Vol 43 No. 4, 400-416.

Kumar, S., \& Rao, P. (2015), A conceptual framework for identifying financing preferences of SMEs. Small Enterprise Research, Vol. 22 No. 1, pp. 99-112.

Lawrence, J., \& Tar, U. (2013), The use of Grounded theory technique as a practical tool for qualitative data collection and analysis. The Electronic Journal of Business Research Methods, Vol. 11 No. 1, pp. 29-40.

Luckmann, T., \& Berger, P. L. (1966), The Social Construction of Reality: A Treatise in the Sociology of Knowledge (New Edition). New York and London: Penguin.

Muniesa, F. (2011), A flank movement in the understanding of valuation. The Sociological Review, Vol. 59, No. s2, pp. 24-38.

National Bank of Rwanda. (2010), National Bank of Rwanda, Annual Report (Annual Report). Kigali, Rwanda.

O’Reilly, K., Paper, D., \& Marx, S. (2012), Demystifying Grounded Theory for Business 
Research. Organizational Research Methods, Vol. 15 No 2, pp. 247-262.

Sahar, L., \& Anis, J. (2016), Loan officers and soft information production. Cogent Business \& Management, Vol. 3 No 1, pp. 1-11.

Scott, J. (1999), Seeing Like a State: How Certain Schemes to Improve the Human Condition Have Failed (New edition edition). New Haven: Yale University Press.

Sherpa, D. (2013), Critical Evaluation of Basel III as Prudential Regulation and its Consequences in Developing Countries' Credit Needs. In EY International Congress on Economics. No. 253, pp. 1-19. Ankara, Turkey: Ekonomik Yaklasim.

Uchida, H., Udell, G. F., \& Yamori, N. (2012), Loan officers and relationship lending to SMEs. Journal of Financial Intermediation, Vol. 21 No. 1, pp. 97-122.

van Hoyweghen, I. (2014), On the Politics of Calculative Devices. Journal of Cultural Economy, Vol. 7 No. 3, pp. 334-352.

Vatin, F. (2013), Valuation as Evaluating and Valorizing. Valuation Studies, Vol. 1 No. 1, pp. $31-50$. 